\title{
BACKGROUND FACTORS OF THAI STUDENTS' SPEAKING ACHIEVEMENT IN ENGLISH LEARNING
}

\author{
Nurulhuda Marudin', Dwijani Ratnadewi ${ }^{2}$, Waode Hamsiah ${ }^{3}$ \\ English Education Department, Faculty of Teacher Training Education Muhammadiyah of Surabaya \\ nurulhuda.marudin@gmail.com
}

\begin{abstract}
In learning English as Foreign Language, there are many background factors that play important roles to be success in learning. In the case of foreign students who study English in non-English speaking country, these factors become more complex. This study aims to analyze the background factors of Thai students' speaking achievement and the different background factors between student's high and low scores of speaking achievement. This study used mixed method design as method of study. The theories of factors were used to answer the objective of this research such as self-esteem, inhibition, risk-taking, anxiety, empathy, extroversion, introversion, motivation, attitude, language exposure, and social situation. The subject was five students from Thailand who studied at Muhammadiyah University of Surabaya. The finding was that each of students mostly possessed different background factors. However, their intensity and ability were different among of them. All of those factors were greatly influence their acquiring of TEFL as well. There were two students who had the highest and lowest scores in their speaking achievement after several years they have learned English in Indonesia. The different background factors between both of them were self-esteem, inhibition, risk-taking, anxiety, extroversion, introversion, attitude, and social situation factors. Their background factors in speaking were supported by many factors to reach a good achievement. Therefore, the factors mainly play important roles to tend students learning foreign language successfully.
\end{abstract}

Keyword: Background factors, Speaking achievement, Thai students, English as a Foreign Language

Many people want to acquire this language whether as a second or a foreign language especially to be capable to speak English as the main point for learners who study English. Speaking is one of English skills for learners giving emphasis to be able to speak English in advance more than other skills. "The mastery of speaking skills in English is a priority for many second-language or foreign-language learners", Richards (2008: 19). However, the English as a Foreign Language (EFL) for the learners may face the difficulty in learning English because they do not speak English in daily life as like the English as Second Language (ESL) for the learners. It should have some factors to push students to achieve the goal in their learning English whether it is successful or not.

To be a successful student in learning English needs the inspiration or encouragement to force them achieving the target language. There are factors that are essential to build the spirit positively such as personality factors, motivation, attitude, social situation factors and so on for influencing people to learn English efficiently. Hussein El-Omari (2016) claims, "Learning English involves many factors that would affect the process of learning positively or negatively". Some students who learn English as a foreign language have a big problem in speaking because they are not accustomed to using English in daily life.

Indonesia is a country where people use English as foreign language the same as some Asian countries such as Thailand, Laos, Vietnam and etc. The students who study aboard will possess more than one language or become bilingual as their own special ability of language. There are many problems for foreigner to acquire English language when they are in non-native 
English speaking country because logically they acquire local language more than English even though they are as foreigners. Many Thai students are studying English in some universities in Indonesia. They have been studying English in Indonesia as foreign language or target language in non-native English speaking environment. This fact makes some difficulties for them to speak English because they just use English in the classroom and they have limited environment to speak or use English more than Indonesia language. It gives the impact that they feel uncomfortable and fear in speaking English.

This research is focused on Thai students in Surabaya who study English Department in 6, 8 semester and an alumni of Muhammayah University of Surabaya. The reason for doing the research is because they have been studying in Indonesia for three or four years and most of them can communicate the local language fluently but their English is not as good as the local language. This study is emphasized on the underlying factors of learning English to speak English with certain case that they are studying English in non-native English speaking country that is Indonesia. I think that it is unique situation where people learn English in non-English speaking country. So, those Thailand students are in fact foreigners from Thailand but learning English in here in Indonesia that it will make them getting more challenge to speak English. They only get their English from the activities in the classroom.

In this case, this study emphasizes on the observing the factors that have made the learner to learn English successfully. The factors are indicated as a key to help learner reaching the goal in their learning the target language. Hence, the writer uses title "Background factors of Thai students' speaking achievement in English learning" to present in this final project. The writer wishes that this study would give the contribution to Indonesia people or teachers who have foreigner as students to understand what learners have faced in English learning through various factors to success in target language.

\section{REVIEW OF LITERATURE}

\section{Speaking Achievement}

The achievement of speaking is desired to get success along the learning process by students who learn English to speak English well. According to Richard (2008: 19), learners usually assess the success in language learning especially in speaking proficiency because it is shown how far they have learned English effectively. It means that speaking is an important skill, because speaking is considered as one of the achievements in learning foreign language.

\section{Factors in speaking achievement}

Factor is an important thing to consider during the process of learning second or foreign language to contribute a student having inspiration to be successful student in the target language. Hussein El-Omari (2016) claims, "Learning English involves many factors that would affect the process of learning positively or negatively". It means that along the process of learning English, the factors are included to give the impact to the students whether inside of negative or positive to them. Most of students have faced many problems along the learning process especially for English as Foreign Language (EFL) because the unnatural situation of speaking English especially in certain situation like in the classroom. Hence, it is crucial thing to overcome difficulties of students by identifying factors to encourage them to be successful student.

\section{a) Self-esteem}

Self-esteem refers to people self-worth or self-respect on themselves that it is a motivation to lead people to success in life. In other words, self-esteem is as how people appreciate, love or respect themselves.

\section{b) Inhibition}


Inhibition is a feeling of worried or embarrassed to block own self to do something. In language learning, it is usual of students to feel worried and shy on what they do not master like speaking until they avoid saying or doing what they want.

\section{c) Risk-taking}

Risk-taking is the act to do something that involves danger and the result can approve or disapprove to achieve the goal in learning language. Brown (2007: 160) claims, "Risk-taking is an important characteristic of successful learning of a second language. Learners have to be able to gamble a bit, to be willing to try out about the language and take the risk of being wrong."

\section{d) Anxiety}

Anxiety is defined as an affective disorder that if people are always getting fear in extent overtime, it can give the worse impact to them in daily activities. Scovel as cited in Brown (2007: 151) stated that uneasiness, frustration, self-doubt, apprehension, or worry was accustomed to anxiety. In addition, anxiety is internal factor to make learning getting success in low anxiety condition because it helps the student simply acquiring language and reduces the student's stress to get input for reaching the goal in acquiring second language.

\section{e) Empathy}

Empathy plays an important role on language learning because it is about how someone put his/her feeling on another person or the ability to understand other person's feeling or though. Brown (2007: 153) states, empathy is a process where people can understand others feeling. It means that empathy is as the way of reading and understanding other's feeling and putting his/her being in the heart of other person.

\section{f) Extroversion}

It is defined as a person who is characterized by talkativeness, activeness, friendliness and sociability that when the learner whose extroversion tends to find social relationship with others.

\section{g) Introversion}

Introversion is a person who is introvert do not talk too much, shy and rarely associate with other but he/she will have strong relationship although having a few friends. In the learning process, the character of introvert person may give the effect on learning if they are shy and keep silent that it makes them unconfident to shine their ability.

\section{h) Motivation}

Based on Grass and Selinker (2008:520) says, motivation is the property that it gives the motive to learn the language. It means that motivation is known as the stimulus to force or push the student having the positive inspiration on learning the language.

\section{i) Attitude}

Attitude is defined as how someone feels and believes to react on something such as people, place, thing and so on. Based on language learning, there are many experts have argued attitude with different perspective. According to Ortega (2013:174), that the attitude to language learning can contribute the learner required to learn second language and it will help to increase second language motivation. It means that the attitude gives the impact to people interested to want learning the language and it is also related to motivation because who have positive attitude can cause increasing the motivation to learn target language.

\section{j) Language Exposure}

The exposure is a way of student to get the better in language acquisition for instance the more students read and listen English, the more they have chance in acquiring the language. k) Social Situation 
The situation of student in learning language have different situation based on the context they have faced such as learning English as second or foreign language. According to Steinberg and Sciarini (2006:130) that the most crucial of social situation have three categories which are the natural, the classroom and the community context.

\section{METHOD OF THE RESEARCH}

This research analyzed the background factors on speaking achievement of Thai students who are studying in English Department at Muhammadiyah University of Surabaya. This study focused on what factors might influence the speaking achievement of the non-native English speaker environment in spite of the fact that all of them are foreigners themselves. Therefore, it guided the writer to use mixed method design as the method of research to analyze and describe how the factors have influenced these Thai students in speaking English as their foreign language. This research used three research instruments to collect the data such as

\begin{tabular}{|l|l|c|c|c|c|c|}
\hline \multirow{2}{*}{ Questions } & The Factors & \multicolumn{5}{|c|}{$\begin{array}{c}\text { Percentage response of background factors } \\
\text { by student A }\end{array}$} \\
\cline { 3 - 7 } & & $\begin{array}{c}\text { Strongly } \\
\text { agree }\end{array}$ & Agree & Natural & Disagree & $\begin{array}{c}\text { Strongly } \\
\text { disagree }\end{array}$ \\
\hline Q. 1-3 & Self-esteem & 67 & 33 & 0 & 0 & 0 \\
\hline Q. 4-9 & Inhibition & 0 & 0 & 0 & 33 & 67 \\
\hline Q. 10-15 & Risk-taking & 17 & 50 & 33 & 0 & 0 \\
\hline Q. 16-19 & Anxiety & 0 & 0 & 25 & 25 & 50 \\
\hline Q. 20-23 & Empathy & 75 & 25 & 0 & 0 & 0 \\
\hline Q. 24-26 & Extroversion & 33.34 & 33.34 & 33.34 & 0 & 0 \\
\hline Q. 27-29 & Introversion & 0 & 0 & 33 & 67 & 0 \\
\hline Q. 30-38 & Motivation & 67 & 11 & 22 & 0 & 0 \\
\hline Q. 39-41 & $\begin{array}{l}\text { Attitude } \\
\text { (positive) }\end{array}$ & 33 & 0 & 67 & 0 & 0 \\
\hline Q. 42 & $\begin{array}{l}\text { Attitude } \\
\text { (negative) }\end{array}$ & 0 & 0 & 0 & 0 & 100 \\
\hline Q. 43-45 & $\begin{array}{l}\text { Language } \\
\text { exposure }\end{array}$ & 0 & 33 & 67 & 0 & 0 \\
\hline Q. 46-51 & Social situation & 50 & 50 & 0 & 0 & 0 \\
\hline
\end{tabular}

documents, questionnaire, and interview. The documents were taken from speaking scores as document of Thai students since they have learned from the first year until third year or four years. It is used to see their achievement in speaking subject and support the data to get stronger data of this research. While the questionnaire, the writer used close-ended questionnaire to obtain data about the activities of using English on spoken by Thai students to seek out the underlying factors has tended the participants in speaking achievement. The writer also interviewed some participants to get more confirmation at specific questions that appear out of the questionnaire. It is used to know the deeper about the interesting psychological factors found by students that it was contrary with the theories in the questionnaire.

\section{FINDING}

The finding of this study were analyzed by each participant's background factors of speaking achievement and the different background factors between student's high and low scores of speaking achievement. 


\section{Table 1 The Background Factors of Student A In Speaking Achievement}

Student A has high self-esteem to believe on herself to speak English. She has low inhibition and high risk-taking to be brave in taking a risk to speak English. Besides, the student has low anxiety when she speaks English and has positive empathy to be an open mind to perceive and understand others. It can be seen that she has high extroversion characteristic more than introversion factor. It means that her character may be a part of her achievement. She has very high motivation in learning and speaking English. There are two aspects of the questions on attitude factor, which are positive and negative, the student possesses positive attitude to join and participate the English speaking class and she prefers to speak English. Moreover, she experiences high language exposure factor through many listening or reading English in her daily activities. Finally, she also has positive social situation where she prefers to communicate with friends or lecturers in English that it may make her to get the good impact on speaking achievement.

Table 2 The Background Factors of Student B In Speaking Achievement

\begin{tabular}{|l|l|c|c|c|c|c|}
\hline \multirow{2}{*}{ Questions } & \multirow{2}{*}{ The Factors } & \multicolumn{5}{|c|}{ Percentage response of background factors by } \\
Student B
\end{tabular}

It can be illustrated that student B possesses low self-esteem and high inhibition to believe and to be confident on himself in speaking English. Besides that, he gets low risktaking meaning he has low courage to take a risk like trying to speak English and high anxiety when he has to speak English. Based on the table 2, he has clearly positive empathy towards others, but in contrast, he reaches balance on extroversion and high introversion factors. With these characteristics, he may prefer to keep silent and participate less actively, which may give the negative impact to his speaking achievement. On the positive and negative attitude aspects, there is the controversy phenomenon in student B where he has positive attitude on learning English but he seems less interested to speak English. Then, he possesses high exposure on listening, reading and watching the language to support on his English knowledge, but in contrast, he has negative social situation to be brave in speaking English with others. 
Table 3 The Background Factors of Student C In Speaking Achievement

\begin{tabular}{|c|c|c|c|c|c|c|}
\hline \multirow[t]{2}{*}{ Questions } & \multirow[t]{2}{*}{ The Factors } & \multicolumn{5}{|c|}{$\begin{array}{c}\text { Percentage response of background factors by } \\
\text { student C }\end{array}$} \\
\hline & & $\begin{array}{c}\text { Strongly } \\
\text { agree }\end{array}$ & Agree & Natural & Disagree & $\begin{array}{l}\text { Strongly } \\
\text { disagree }\end{array}$ \\
\hline Q. 1-3 & Self-esteem & 0 & 0 & 67 & 33 & 0 \\
\hline Q. 4-9 & Inhibition & 17 & 33 & 33 & 17 & 0 \\
\hline Q. $10-15$ & Risk-taking & 0 & 0 & 50 & 50 & 0 \\
\hline Q. $16-19$ & Anxiety & 0 & 100 & 0 & 0 & 0 \\
\hline Q. 20-23 & Empathy & 25 & 50 & 25 & 0 & 0 \\
\hline Q. 24-26 & Extroversion & 0 & 0 & 100 & 0 & 0 \\
\hline Q. 27-29 & Introversion & 67 & 0 & 33 & 0 & 0 \\
\hline Q. 30-38 & Motivation & 0 & 44 & 56 & 0 & 0 \\
\hline Q. 39-41 & Attitude (positive) & 33 & 0 & 67 & 0 & 0 \\
\hline Q. 42 & Attitude (negative) & 0 & 0 & 0 & 0 & 100 \\
\hline Q. 43-45 & Language exposure & 0 & 33 & 67 & 0 & 0 \\
\hline Q. 46-51 & Social situation & 0 & 33 & 67 & 0 & 0 \\
\hline
\end{tabular}

The background factors of student $\mathrm{C}$ can be seen that the student has low self-esteem and high inhibition on speaking English. She is also in low risk-taking level illustrating that she takes a less chance to try speaking English, and what is more, she has high anxiety when she has to speak and present in English. It means that the student is afraid to make mistake and worried on her speaking English. Yet, she attains positive empathy to open mind to talk with others in English. The extro-introversion factors are balance although the introversion is a little bit higher. She possesses high motivation to be able speaking English for getting a good chance on her achievement. Based on the positive and negative attitude aspects, she shows positive attitude in learning English and likes speaking English. It means that she believes that learning English is important and she does not reject to speak English. She has balanced language exposure with many reading, listening and others activities which support her English acquisition and she acknowledges that she has positive social situation.

\section{Table 4 The Background Factors of Student D In Speaking Achievement}




\begin{tabular}{|c|c|c|c|c|c|c|}
\hline \multirow[t]{2}{*}{ Questions } & \multirow[t]{2}{*}{ The Factors } & \multicolumn{5}{|c|}{$\begin{array}{c}\text { Percentage response of background factors by } \\
\text { student D }\end{array}$} \\
\hline & & $\begin{array}{c}\text { Strongly } \\
\text { agree }\end{array}$ & Agree & Natural & Disagree & $\begin{array}{l}\text { Strongly } \\
\text { disagree }\end{array}$ \\
\hline Q. 1-3 & Self-esteem & 33.34 & 33.34 & 33.34 & 0 & 0 \\
\hline Q. 4-9 & Inhibition & 0 & 17 & 17 & 66 & 0 \\
\hline Q. 10-15 & Risk-taking & 0 & 50 & 33 & 17 & 0 \\
\hline Q. 16-19 & Anxiety & 0 & 0 & 25 & 25 & 50 \\
\hline Q. 20-23 & Empathy & 0 & 50 & 50 & 0 & 0 \\
\hline Q. 24-26 & Extroversion & 67 & 0 & 33 & 0 & 0 \\
\hline Q. 27-29 & Introversion & 0 & 67 & 33 & 0 & 0 \\
\hline Q. 30-38 & Motivation & 67 & 0 & 33 & 0 & 0 \\
\hline Q. 39-41 & Attitude (positive) & 33 & 67 & 0 & 0 & 0 \\
\hline Q. 42 & Attitude (negative) & 0 & 0 & 0 & 100 & 0 \\
\hline Q. 43-45 & Language exposure & 0 & 67 & 33 & 0 & 0 \\
\hline Q. 46-51 & Social situation & 0 & 33 & 50 & 17 & 0 \\
\hline
\end{tabular}

The student $\mathrm{D}$ gets high self-esteem to believe on herself but low inhibition to be worried when speaking English. She also has high risk-taking to be brave taking a risk whenever she has a chance to speak. This is completed with the low anxiety when speaking English. Besides that, she gains positive empathy towards others. She has similar high options between extroversion and introversion factors although there is slightly higher on extroversion factors. It means that the student has balance characteristic that it may inhibit the student in speaking English. She has high motivation to be able to speak English to get a good opportunity in the future. There are two aspects of attitude factor which are positive and negative, she reaches positive attitude to participate and join the speaking activities in the classroom and then she disagree to reject in speaking English. Based on the table above, it can be seen that she gets very high language exposure to expose the language on reading, listening, and watching that it encourages the student's achievement. Lastly, she attains positive social situation when speaking English.

Table 5 The Background Factors of Student E In Speaking Achievement

\begin{tabular}{|c|c|c|c|c|c|c|}
\hline \multirow[t]{2}{*}{ Questions } & \multirow[t]{2}{*}{ The Factors } & \multicolumn{5}{|c|}{$\begin{array}{c}\text { Percentage response of background factors by } \\
\text { student } E\end{array}$} \\
\hline & & $\begin{array}{l}\text { Strongly } \\
\text { agree }\end{array}$ & Agree & Natural & Disagree & $\begin{array}{l}\text { Strongly } \\
\text { disagree }\end{array}$ \\
\hline Q. 1-3 & Self-esteem & 33 & 67 & 0 & 0 & 0 \\
\hline Q. 4-9 & Inhibition & 0 & 0 & 0 & 50 & 50 \\
\hline Q. 10-15 & Risk-taking & 50 & 33 & 17 & 0 & 0 \\
\hline Q. 16-19 & Anxiety & 0 & 25 & 50 & 0 & 25 \\
\hline Q. 20-23 & Empathy & 100 & 0 & 0 & 0 & 0 \\
\hline Q. 24-26 & Extroversion & 100 & 0 & 0 & 0 & 0 \\
\hline Q. 27-29 & Introversion & 33.34 & 0 & 0 & 33.34 & 33.34 \\
\hline Q. 30-38 & Motivation & 100 & 0 & 0 & 0 & 0 \\
\hline Q. 39-41 & Attitude (positive) & 100 & 0 & 0 & 0 & 0 \\
\hline Q. 42 & Attitude (negative) & 0 & 0 & 0 & 0 & 100 \\
\hline Q. 43-45 & Language exposure & 100 & 0 & 0 & 0 & 0 \\
\hline Q. 46-51 & Social situation & 67 & 33 & 0 & 0 & 0 \\
\hline
\end{tabular}


The student $\mathrm{E}$ has high self-esteem to believe and be confident on her ability to speak English; however, she gets low inhibition to be afraid and worry when the time to speak English. She obtains high risk taking to be brave taking a risk to speak English without afraid of making mistake. Besides, she has mostly balance towards on her anxiety when speaking and slightly high anxiety when presenting assignment in English. Then, she reaches positive empathy to be an open mind to perceive and understand others. It can be seen that she has extreme high extroversion characteristic more than introversion. It means that the extroversion characteristics may give the impact to her achievement in speaking English. In addition, she attains high motivation to be able speaking to reach the goal on what she had expected. She gets positive attitude to join the speaking activities and she seems interested to speak English. Moreover, she reaches high on language exposure that she always exposes the language by listening or reading to enrich her knowledge of English. Finally, she has positive social situation where she is brave to communicate with people around her in English that it makes her getting good result on her achievement.

Table 6 the different background factors of student's high and low score

\begin{tabular}{|c|c|c|c|c|c|c|c|c|c|c|c|}
\hline \multirow[t]{3}{*}{ No. } & \multirow[t]{3}{*}{ Factors } & \multicolumn{10}{|c|}{$\begin{array}{l}\text { Percentage response of background factors by student E } \\
\text { And student B }\end{array}$} \\
\hline & & \multicolumn{2}{|c|}{$\begin{array}{l}\text { Strongly } \\
\text { agree }\end{array}$} & \multicolumn{2}{|c|}{ Agree } & \multicolumn{2}{|c|}{ Natural } & \multicolumn{2}{|c|}{ Disagree } & \multicolumn{2}{|c|}{$\begin{array}{l}\text { Strongly } \\
\text { disagree }\end{array}$} \\
\hline & & $\mathbf{E}$ & B & $\mathbf{E}$ & $\mathbf{B}$ & $\mathbf{E}$ & $\mathbf{B}$ & $\mathbf{E}$ & B & $\mathbf{E}$ & $\mathbf{B}$ \\
\hline Q.1-3 & Self-esteem & 33 & - & 67 & - & - & 67 & - & 33 & - & - \\
\hline Q.4-9 & Inhibition & - & 17 & - & 17 & - & 66 & 50 & - & 50 & - \\
\hline Q.10-15 & Risk-taking & 50 & - & 33 & - & 17 & 67 & - & 33 & - & - \\
\hline Q.16-19 & Anxiety & - & - & 25 & 75 & 50 & 25 & - & - & 25 & - \\
\hline Q.20-23 & Empathy & 100 & 50 & - & 50 & - & - & - & - & - & - \\
\hline Q.24-26 & Extroversion & 100 & - & - & - & - & 100 & - & - & - & - \\
\hline Q.27-29 & Introversion & $\begin{array}{l}33 . \\
34\end{array}$ & - & - & 67 & - & 33 & $\begin{array}{l}33 . \\
34\end{array}$ & - & $\begin{array}{l}33 . \\
34\end{array}$ & - \\
\hline Q.30-38 & Motivation & 100 & 78 & - & 22 & - & - & - & - & - & - \\
\hline Q.39-41 & $\begin{array}{l}\text { Attitude } \\
\text { (positive) }\end{array}$ & 100 & - & - & 33 & - & 67 & - & - & - & - \\
\hline Q.42 & $\begin{array}{l}\text { Attitude } \\
\text { (negative) }\end{array}$ & - & - & - & 100 & - & - & - & - & 100 & - \\
\hline Q.43-45 & $\begin{array}{l}\text { Language } \\
\text { exposure }\end{array}$ & 100 & $\begin{array}{l}33 . \\
34\end{array}$ & - & $\begin{array}{l}33 . \\
34\end{array}$ & - & $\begin{array}{c}33.3 \\
4\end{array}$ & - & - & - & - \\
\hline Q.46-51 & $\begin{array}{l}\text { Social } \\
\text { situation }\end{array}$ & 67 & - & 33 & 16 & - & 67 & - & 17 & - & - \\
\hline
\end{tabular}

In the table six above shows the different background factors between student's high and low scores of speaking achievement. Student E got the highest scores among five students because the overall average grade was 4 (four) from the total scores in speaking class which were Speaking For Daily Conversation, Speaking For Discussion, Speaking For Debate, and Public Speaking. Conversely, student B got the lowest scores among other students since the overall average grade was 2.3 (two point three) from the speaking class that were Speaking I, Speaking II, and Speaking III, and Speaking For Debate. It can be seen that the different 
background factors between both of them are self-esteem, inhibition, risk-taking, anxiety, extroversion, introversion, attitude, and social situation factors.

\section{DISCUSSION}

The background factors of each participants have the different background factors each of them because they have different intensity and ability among them. This makes them possess different achievement in speaking as well. Their background factors are supported by many factors to encourage them to get a good achievement.

There are some interesting psychological factor found which contradicts with the theory in their speaking achievement. Student B, student D, and student E have found that their character contrary with theories of attitude, extroversion, introversion, and anxiety. The writer has interviewed three of them to make this phenomenon understandingly. Although there are some factors that it may hinder them to speak such as student B has positive learning English but he does not like to speak English, student D has same high of extroversion and introversion characteristics, and student $E$ has a balanced anxiety character. It is truly known that the factors inspire students in learning English successfully but it would not achieve the success if it were without struggling to reach the goal.

\section{CONCLUSION}

Student A has a higher of self-esteem, risk-taking, empathy, extroversion, motivation, attitude, language exposure and social situation but she has a lower of inhibition, anxiety and introversion factors. While, student B possesses high inhibition, anxiety, empathy, introversion, motivation and language exposure but he possesses low self-esteem, risk-taking, extroversion, attitude and social situation factors. For student $\mathrm{C}$, she attains a higher level of inhibition, anxiety, empathy, introversion, motivation, attitude, language exposure, and social situation, however, she also has low self-esteem, risk-taking, and extroversion factors. Besides that, student D gets high self-esteem, risk-taking, empathy, motivation, attitude, and social situation factors yet she gets a lower of inhibition and anxiety. She has balance extroversion and introversion characteristics. Other student is student E, she has high self-esteem, risktaking, empathy, extroversion, motivation, attitude, language exposure, and social situation factors but she possesses low inhibition and introversion. She has a balanced anxiety character as well.

There are students who get the highest and lowest scores to know their different background factors in speaking achievement. Student E is a student who has highest score, while student $B$ is a student who has lowest scores among five students. Both of student $E$ and $\mathrm{B}$ have the different background factors to give impact on their achievement in speaking. The overall of different background factors of student's high and low scores in speaking achievement are self-esteem, inhibition, risk-taking, anxiety, extroversion, introversion, attitude, and social situation factors.

The different background factors between student $\mathrm{E}$ and student $\mathrm{B}$ in speaking achievement obviously indicate that to be a successful student in speaking has to encourage by many factors to get the goal. Conversely, the failure in speaking English is natural learning process but the factors can contribute the student to be able to have a force to attain speaking proficiency. Hence, the speaking achievements of both students are different in many aspects in fact all of achievement is depended on student's effort as well to achieve the goal to make them getting the different achievement. 


\section{REFERENCES}

Brown, H. Douglas. 2007. Principles of language learning and teaching : San Francisco State University.

Grass, Susan., Selinker, Larry. Second Language Acquisition. New York : Routledge.

Hussein El-Omari, Abdullah. 2016. Factors Affecting Students' Achievement in English Language Learning. Journal of Educational and Social Research. Vol . 6(2)

Richards. ( 2008 ) : Teaching Listening and Speaking From Theory to Practice. Cambridge: Cambridge University Press.

Ortega, Lourdes. 2013. Understanding Language Acquisition. New York: Routledge.

Steinberg, Danny., Sciarini, Natalia. An Introduction to Psycholinguistics. Britain : Pearson Education Limited. 